\title{
JOUR N A
}

\section{OF TH: \\ F IR A N LIN I NSTITUTE \\ OF THE}

State of pennsplbanta,

A $\$ D$

MEOIANIOS, REGISTIR.

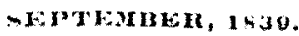

سח

\section{Civil Engineering.}

Conparison of the Rail Roads of Belgitum with those of the United States. By the Chevalien de Gerstrer.

The rapid increase of Internal Improvements in the United States has excited for several years public attention in Europe, and the friends of those improvements desired very much a detailed report on the extent and progress of those works, and particularly of Rail Roads. There is no such report published in the United States, and even those published in England, France, and Germany are very imperfect.

In 182.1 I had charge of the first Rail Road on the continent of Europe, to connect the rivers Moldau and Danube in Austria, by a line which is one bundred and thirty miles long, and which has been in operation since $183 \%$. 1 constructed in 1836 and 1837 the first Rail Road in Russia, from St. Petersburg to Zarskoe-Selo and Pawlowsk, a line of only 17 miles in length,. but forming the commencement of a Rail Road of four hundred and twenty miles from st. Petersburg to Moscow. This Rail Road being likewise in full operation, I left Europe last fall and arrived in the Great Western on the $15 \mathrm{th}$ of Xovemuer, 1838, at New York. After a short stay of a few days 1 went to Albany, and inspected all the Rail Roads between that place and Lake Erie; I then proceeded to the Eastern States and visited all the Rail Roads in Massachusetts, and went via New York, Philadelphia, Baltimore, and Washington, through Virginia, North and South Caroliria, Georgia, and Alabama, to New Orleans, always visiting the Rail Road lines in the dif ferent States. I went then up the Mississippi and Ohio, and am now abgut inspecting the Internal Improvements of the Western States, and sonetof those in Pennsylvania, which I have not yet seen.

I have already passed over more than two thousand miles of Rail Road $\mathbf{s}$, and have every where been received with the greatest kindness; the Presidents, Directors and Engineers of the different Rail Rond lines gave me

Vox. XXIV.-No. S.-SEPTEMBER, 1839. 13 
not only all their printed reports, but laid before me, with the greatest liberality, their books and accounts, in order to aftord me every kind of in. formation. I fulfil only my duty when I publicly acknowledge, that such a liberality is only to be found amongst a free and enlightened people, where all public works are based on the principle of publicity, and where secrets do not exist. I wish, therefore, to make those gentlemen, to whom I am so much indebted, another communication, which will show at the same time what has been done during the last years in Europe. Having within a few days received the last Reports on the Belgian Rail Roads, I publish in the following abstract the history and progress of those communications in Belgium, together with a comparison of them with the American Rail Roads.

According to the facts collected during my travels since my arrival in New York, there are now over three thousand miles of Rail Roads completed and in operation in the Uniled States; four hundred and twenty-five locomotives, of which the greatest number were made in this country, run on the several Rail Roads, and I believe, that up to the end of 1839 , the length of Rail Roads in the United States may amount to forty-one hundred miles. The capital expended on the Rail Roads now in operation is about sixty millions of dollars, or at an average cost of twenty thousand dollars per mile, for which sum the Rail Roads, with the buildings, have been constructed, and the necessary locomotives and cars bought.

Several Rail Roads have been undertaken with insufficient means, and the shareholders found themselves under the necessity of employing the income of the first years in improving the Rail Road, in building engine. houses, \&c. and purchasing locomotives and cars. In consequence of this the shareholders got during that time no divitlends, but the Rail lioad still yielded a good income. Other Rail Roads, when finished, paid from five to ten per cent. income to the stockholders; others have not yet paid any dividends for want of a sufficient number of passengers and freight. The average result of the Rail Roals now in operation in the United States is, that they give a yearly interest of five and a half per cent. on the capital invested. This result must be regarded as very satisfactory, because the greatest part of the lines have only been a few years in operation.

On all lines there is a yearly increase of at least from fifteen to twenty per cent. in the gross income, so that even those lines which do not pay now will give in a few years a handsome dividend. According to these statements, based on the communications collected in this country, I have no doubt, that the large capital invested in Rail Roads, in the United States, will not only produce an incalculable benefit to the country, but likewise pay the shareholders a dividend, which under good management, by the constant progress in population and trade, must likewise from year to year increase.

Good book-keeping and clear accounts are matters of importance in every business; Rail Roads are new constructions, and experience, particularly in working them, is still very much wanted. When the Superintendent of a Rail Road in operation keeps clear and distinct accounts, he will in a few years learn by experience what can be improved, and which items of expenses can be reduced. The following statement contains a manner of making the Rail Road accounts, which, in my opinion, must prove very useful for every Rail Road Company.

I. History, Length and Cost of Construction of the Belgian Rail Roads.

The Rail Roads, which up to the present time have been constructed in 
England and on the continent of Europe, had no other object than to con. nect two important places of the country, and in constructing them, therefore, local interest more or less prevailed. That Rail Roads are to be con. silered as great thoroughfares, that they can form in a country the principal lines of internal communication-that, therefore, the means for their establishment should be such, as only can be raised by a whole nation, nobody in Europe would have maintained previous to 1834, and it is even now denied by many individuals of high standing and influence. Belgium, united with Holland since 1815, had distinguished itself in Europe, by its fine roads, and magnificent canals; the latter, being constructed, for the greatest part, in a level country, and without locks were used not only for the transportation of goods, but also for passengers, especially the lower classes, which there, more than in any other country, made use of the canal boats for their travels. It is evident, that no individuals. would ever have attempted to construct Rail Reads parallel, and in opposition, to such canals and turnpike roads.

In the year 1830, Belgium declared itself independent of Holland, and electel by the representatives of the nation its own sovereign. KING Leo. roun $\mathbb{I}$. soon discovered, that the country, for its perfect tranquillity, wanted "labour," a series of wise legis!ation encouraged the nation to useful and profitable enterprizes, and every person with talent and inclination found cmployment and earnings in a country, which isolated from all its neighbours, was confined to its own resources. But to gain over public opinion, a great national work was to be accomplished by the new government, which might fill posterity with admiration. The time was past for Egyptian pyramids, for Roman triumphal arches, and French monuments of war. A wore usefal monument, one of peace and intelligence, was to remind the nation of that eventful period. The King ordered the whole country to be surveyed by able Enrineers, the necessary plans and estimates formed, and on the first of May 1834, a law was proclained, according to which a sys. tem of Rail Roads was to be introduced through the whole kingdom, and executed at the expense of the State; on two points (at Antwerp and Ostend). the Rail Roads were to lead to the seaports, on two points to connect with France, and on one point with Prussia (Germany.)

The news of the gigantic work, undertaken by a State, even not yet ac. knowledged as such by the northern powers, and with only four millions of inhabitants, excited the greatest surprise in Europe, and few only could conceive the great results, which this grand project must necessarily pro. duce on the independence of the nation and its internal welfare, its commerce and industry; the former being the principal aim and the promotion of commerce and industry a subordinate one, although the great mass of the people were unable to comprehend the grand idea of the plan.

Krxe Lropord found in his former minister of public works, Mr. De Theux, and in his successor, Mr. Nothomb, vigorous supporters. The Engineers were vieing in the swift prosecution of the work, and, in the course of four years, more has been done than was expected. The enlightened minister Nothomb published annual reports to the Legislative Assembly, besides other special reports of the progress of the works, in which the public in Europe find a rich source of experience, not to be met with in any other report or work on the subject. Europe has to render thanks to the King, who the first realized such a grand idea, and to his enlightened minister, who judiciously conducted the work, and so liberally communicated its results, 
The limited space of this report does not allow a detailed extract frone the above mentioned reports of the minister Nothomb and the Engineers; shall therefore only give a brief account containing the results in numbers, and afterwards compare these results with those of Rail Roads in the Uniteci States. The following table contains the sections of the Rail Roads which were opened up to the end of 1838 , and their lengths in metres and English miles.

\begin{tabular}{|c|c|c|c|c|}
\hline \multicolumn{2}{|c|}{ Sectros oe Ran Roan. } & \multirow{2}{*}{ Time of opening. } & \multicolumn{2}{|c|}{ Lenatk. } \\
\hline From & To & & $\begin{array}{l}\text { In French } \\
\text { mètres. }\end{array}$ & $\begin{array}{c}\text { In Englist. } \\
\text { miles. }\end{array}$ \\
\hline $\begin{array}{l}\text { Brussels, } \\
\text { Malines, } \\
\text { Milines, } \\
\text { Malines, } \\
\text { Jouvain, } \\
\text { Termonde, } \\
\text { Tiriemunt, } \\
\text { Warcmme, } \\
\text { Gent, } \\
\text { Bruges, }\end{array}$ & $\begin{array}{l}\text { Malines, } \\
\text { Antwerp, } \\
\text { Termonde, } \\
\text { Louvain, } \\
\text { Tirlemont, } \\
\text { Gent, } \\
\text { Waremme, } \\
\text { Ans, } \\
\text { Bruges, } \\
\text { Ostend, }\end{array}$ & $\begin{array}{l}5 \text { May } 1835, \\
3 \text { May } 1836, \\
2 \text { January } 1887, \\
10 \text { September } 1837, \\
22 \text { September 1837, } \\
28 \text { September } 1837, \\
2 \text { April } 1838, \\
2 \text { April } 1838, \\
12 \text { August } 1838, \\
28 \text { August } 1838,\end{array}$ & $\begin{array}{l}20,300 \\
23,500 \\
26,700 \\
23,750 \\
17,750 \\
30,500 \\
27,200 \\
18,900 \\
44,500 \\
23,500\end{array}$ & $\begin{array}{l}12.5 \\
14.6 \\
16.5 \\
14.7 \\
11.9 \\
18.9 \\
16.8 \\
11.7 \\
27.6 \\
14.6\end{array}$ \\
\hline & & Total, & 256,600 & 159.0 \\
\hline
\end{tabular}

According to the report, made by the minister to the house of Representatives, on the 26th November 1838 , the above ten sections including bu il a ine, locomotives and cars cost thirty four millions of francs; this gives per mile of Road forty-one thousand three hundred dollars. The Rail R Oa from Brussels to Antwerp, 27.2 miles, has a double track, the remainder are constructed with only a single track, the rails weighing forty-fi $*$ poinds per yard. But there are several buildings yet to be erected, and different works on the line to be executed, and besides a number of freight cars to be provided for, \&c.; with all this the cost per mile will amount ts: forty-five thousand dollars.

\section{Tariff for Passengers, Speed.}

There are on the Belgian Rail Roads four classes of passenger cars, differing only in elegance and comfort, but going in the same train, and the cefore with equal velocity. The prices are:

In the Berlines, . . $2 \frac{1}{3}$ cents per mile, ?

"Diligences, . . 2 " " " " For each Passenger with

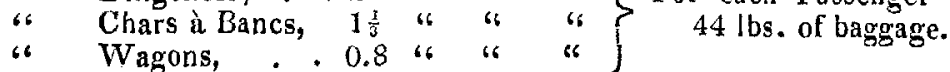

The trains perform at an average of seventeen English miles per hour, a 11 stoppages included, or from twenty to twenty-five miles while running.

III. Traffic and Revenue on the Betgian Rail Roads.

The Rail Roads in Belgium are frequented by more passengers than an $y$ other Rail Roads; the transportation of freight was only begun between Brussels and Antwerp, in 1838. The following table shows the travel since the opening of the first section, until the 31st of October 1838. 


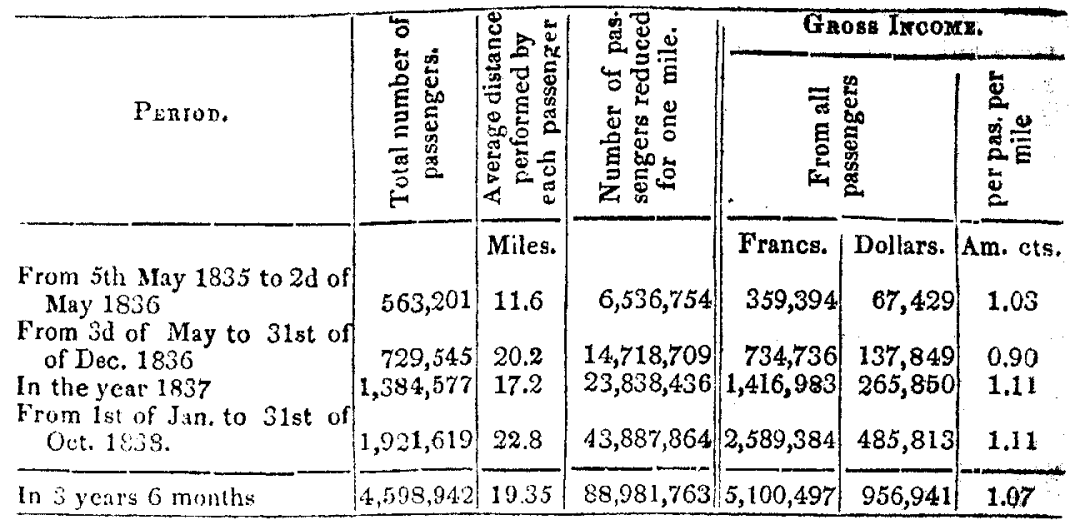

to which must be added forty-four thousand one hundred and forty-eight francs, or cight thousand two hundred and eighty-one dollars, as the gross income from freight in the year 1858.

In the year 1837 , there were anong the number of passengers, thirty thousand eight hundred and fifty-seven soldiers, for whom, in consequence of an arrangement with the ministry of the War Department, only half price was paid.

In 1838 the total number of passengers amounted, according to the "Moniteur Belge," to two million two hundred and thirty-eight thousand three hundred and three, comprising fifty-six thousand six hundred and eighteen soldiers, and the gross income was three million one hundred thousand eight hundred and thirty-three francs forty centimes (five hundred and cighty-one thousand seven hundred and seventy dollars). As the average distance performed by each passenger in the first ten months of 1838 is not mentioned in the Report of the Minister, I have supposed the income per passenger per mile to be the same as in 1837 , out of which results an average distance of 22.8 miles. In order to show how the traveling public male use of the different classes of cars, the following contains the number of passengers in each class of cars, and the revenue resulting there. from for the year ending 51 st December 1838. During this period there were

17,503 passengers, 1. class, who paid 69,322 francs 65 centimes. 215,893 " " II. class, or 702,502 francs 70 centimes. 604,935 " "III. class, " $1,033,953$ francs 05 centimes. $1,543,354$ " IV. class, 6 $1,087,790$ francs 45 centimes. 56,618 soldiers, "6 45,248 francs 88 centimes.

For overweight of bag. and freight, 162,015 francs 67 centimes.

$2,258,303$ passengers and total income, $3,100,833$ francs 40 centimes. These numbers explain sufficiently that the Rail Roads in Belgium are used principally by the lower classes of the people.

\section{Cost of working the Belgian Rail Roads.}

The accounts kept under this head contain an exact subdivision of the different expenses occurring in working the Rail Roads; the first general subdivision contains the maintenance of way and polies the second the cost of transportation, viz. fuel, engineers and firemen, repairs of locomo. 
tives and cars, grease for the same, also the expenses for conductors, carriers and baggage men; the third embraces the general expenses, viz. clerks and ticket sellers, comptrollers, printing, advertising, office expenses, \&ic. The annexed table contains the expenses under the different heads:

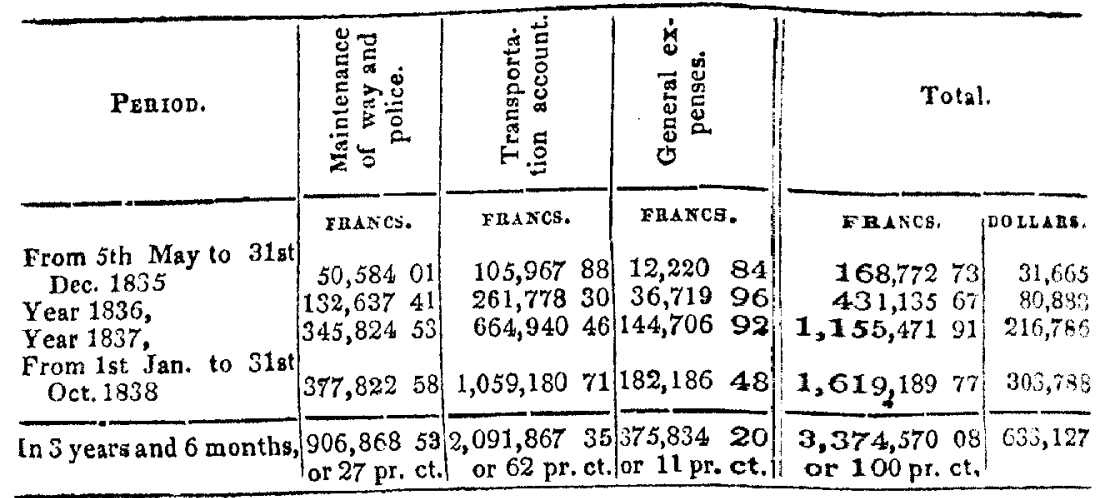

As this table contains the expenses of working the Rail Roads three and a half years, these numbers may certainly be regarded as the result of a great experience.

\section{Cost of Repairs of Locomotives and Cars.}

In the last table the sum of one million fifty-nine thousand one hundred and eighty francs, seventy-one centimes, appears under the head of trans. portation account for ten months in 1838. This sum contains the gxpenses for foremen in the shops,

For labourers expenses, . . . 197,4635.6ic.

At the principal shops in Malines, . . . $54,868 \mathrm{f}$. 72c.

For materials for repairs, . . . . $87,965 \mathrm{f} .66 \mathrm{c}$.

Total, $362,475 \mathrm{f} .53 \mathrm{c}$.

or sixty-eight thousand and six dollars, which is 34 per cent. of the expenses of transportation. I believe that the expenses for repairs of engines and cars might be diminished by the introduction of locomotives with move. able trucks in front, and of eight wheeled passenger and freight cars.

\section{Expenses per Passenger per Mile.}

The accurate number of miles performed by passengers not being con. tained in the last report, the expenses per passenger per mile can only be found up to the end of $183 \%$. According to the last statement, the ex. penses from the 5 th of May 1835, to the 319t of December 1837, were:

$$
\begin{aligned}
& \text { For maintenance of way, . . . - \$29,045f. } 95 \mathrm{c} \text {. } \\
& \text { Transportation account, . . . . 1, 032,686f. 64c. } \\
& \text { General expenses, . . . . 193,647f. 720. } \\
& \text { 1, } 755,380 \text { f. 31c. }
\end{aligned}
$$

During the same period the number of passengers reduced to 1 mile was equal to forty-five million ninety-three thousand eight hundred and ninety. nine, which divided in the above ratio gives as the expenses per passenger per mile, 


\section{For maintenance of way, . . $\quad 1.17$ centimes, or 0.22 cents. Transportation account, . . . 2.29 centimes, or 0.43 cents. General expenses, . . . 0.43 centimes, or 0.08 cents.

These expenses are very low, and are exceeded on every other Rail Road. VII. Expenses per Mile of Travel.

The number of miles performed by all the locomotives with their trains was:
From 5th May 1835, to 24 May 1836,
From Sd May 1836, to 31 st December 1836, . . 24,825 lieves.
Fron 1st January 1837, to 31 st December 1837, . 61,592 lieues.

Total, 101,227 lieues. at five thousand metres, or three hundred and fourteen thousand five hundred and six English miles; the expenses during the same period of two years and 8 months were

For maintenance of way, $5 z 9,045 f .95 \mathrm{c}$.

- 1f. 68c. or $31 \frac{x}{2}$ cents.

For transportation account, $1,032,686$ f. $64 \mathrm{c}$. 3f. $28 \mathrm{c}$. or $61 \frac{2}{2}$ cents.

General expenses, $\quad 193,647$ f. $72 \mathrm{c}$. Of. 62c. or 12 cents.

\section{Total, $\overline{1,755,380 f .31 \mathrm{c} .} \overline{5 \text { f. } 58 \mathrm{c} .}$ or $\overline{105}$ cents.}

The expenses for every mile which a locomotive with its train runs, amount therefore to five francs fifty-eight centimes, or one dollar and five cents, being very nearly the same as on the American Rail Roads.

\section{FIII. Number of Passengers per Trip.}

In the table No. 1ll., we have shown that the number of passengers from the 5 th of May 1835 , to the 31 st of December 1857, reduced for the length of a single mile of road, amount to forty-five million ninety-three thousand eight hundred and ninety-nine; during the same period the trains performed three hundred and fourteen thousand five hundred and six miles; this gives one hundred and forty-three as the average number of passengers in a train. This number compared with 5f. 58c. as the expenses per mile of travel, gives again $3.89 \mathrm{c}$. or 0.73 cents as the expense per passenger per mile.

\section{Comparison between the Gross Income and the Net Revenue.}

The following table contains the annual gross income, current expenses and the surplus of income over the expenses, as is related in the Report of the Minister, of the 26 th of November 1838 , to which is annexed the annual surplus for every one hundred francs of the gross income.

\begin{tabular}{|c|c|c|c|c|}
\hline \multirow[t]{2}{*}{ Pentod. } & $\begin{array}{l}\text { Total gross } \\
\text { income. }\end{array}$ & $\begin{array}{c}\text { Current Ex- } \\
\text { penses. }\end{array}$ & $\begin{array}{l}\text { Surplus of the } \\
\text { revenue over } \\
\text { the expenses. }\end{array}$ & \multirow{2}{*}{$\begin{array}{l}\text { From 100f. of the } \\
\text { gross income re- } \\
\text { mained after de- } \\
\text { fraying all ex- } \\
\text { penses. }\end{array}$} \\
\hline & FRANCS, CENT. & FaAXCB, CENT. & FRANCB, CENT. & \\
\hline $\begin{array}{l}\text { 5th May 1835, to } 3181 \\
\text { Dec. } 1835 \text {, } \\
\text { Year } 1836 \text {, } \\
\text { Year 1837, } \\
\text { Ist Jan. 1838, to } 3181 \\
\text { Dec. } 1838 \text {, }\end{array}$ & 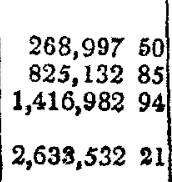 & 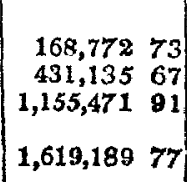 & $\left|\begin{array}{rr}100,224 & 77 \\
393,997 & 18 \\
261,511 & 08 \\
& \\
1,014,342 & 44\end{array}\right|$ & $\begin{array}{l}\text { 37f. } 26 \text { centimes. } \\
\text { 47f. } 75 \text { centimes. } \\
\text { 18f. } 46 \text { centimes. } \\
\text { 38f. } 52 \text { centimes. }\end{array}$ \\
\hline & $5,144,645 \quad 50$ & 57008 & 1,7 & $34 \mathrm{f}$ \\
\hline
\end{tabular}


As an average, therefore, of three and a half years, of every one hundred francs revenue, only thirty-four francs forty-one centimes remained, but as all the locomotives and cars are still new, and no amount for general depreciation appears under the expenses, it is to be supposed, that in future only thirty francs will remain from one hundred. This surplus serves as interest and a sinking fund for the capital.

\section{$X$. Gross Income per Mile of Rail Road.}

The public in Europe is, almost throughout, of opinion, that only short lines, and these especially between two populous cities, will pay a good interest, and that the branch roads extending to remote, less populated, parts of a country will never yield any profit. What results the Belgian roads give in that respect, the annexed table will show:

\begin{tabular}{|c|c|c|c|c|c|}
\hline \multirow[t]{2}{*}{ PERTON. } & \multirow{2}{*}{$\begin{array}{l}\text { No. of } \\
\text { sections } \\
\text { opened. }\end{array}$} & \multirow{2}{*}{$\begin{array}{l}\text { Averago } \\
\text { length of } \\
\text { road in } \\
\text { operation. }\end{array}$} & \multirow{2}{*}{$\begin{array}{c}\text { Gross income } \\
\text { during the } \\
\text { whole period. } \\
\text { ERancs. cent. }\end{array}$} & \multicolumn{2}{|c|}{$\begin{array}{l}\text { Annual income per sin- } \\
\text { gle mile of road. }\end{array}$} \\
\hline & & & & FRANCS, CENT. & DOLIARG. \\
\hline $\begin{array}{l}\text { 5th May to 31st Dec. } 1835, \\
\text { Year } 1836, \\
\text { Year 1837, } \\
\text { 1st Jan. to 31st Oct. } 1838,\end{array}$ & $\begin{array}{r}1 \\
2 \\
6 \\
10\end{array}$ & $\begin{array}{r}12.6 \\
22.3 \\
56.1 \\
118.7\end{array}$ & 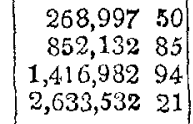 & 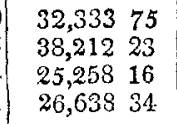 & $\begin{array}{l}6,066 \\
7,169 \\
4,739 \\
4,998\end{array}$ \\
\hline Total, & & 53.1 & $5,144,465 \quad 50$ & $27,735 \quad 98$ & 5,204 \\
\hline
\end{tabular}

In the second column for the year $\mathbf{1 8 5 5}$, appears only the section between Brussels and Malines of 12.6 miles opened at that time. In the year 1836 , these 12.6 miles were in operation for three hundred and sixtyfive days, and the second section from Malines to Antwerp, of 14.6 miles, for two-liundred and forty-three days only. In multiplying the length of each section by the respective number of days, and dividing the sum by three hundred and sixty-five, we obtain 22.3 miles as the average length in operation during the whole year 1836 . In the same manner the average length was obtained for the years 18.37 and 1838 . The last column shows, that the annual receipt per single mile of road amounted in the first year, when the novelty attracted many passengers, and only 12.6 miles were opened, to thirty-two thousand three hundred and thirty-three francs, seventy-five centimes, and that in the third and fourth year, when curiosity attracted but few, and the greatest number travelled for business only, and while a much greater length of road was in operation, these recipts amounted still to twenty-six thousand five hundred francs per mile yearly. This amount will andoubtedly be increased in the following years, as in 1838 four new sections came into operation, on which the traffic will develope itself only by and by; besides there will be the transportation of goods, which for the year 1839 , is estimated to give a revenue of eight hundred and fifty thousand francs for one hundred and fifty-nine miles, or five thousand three hundred and forty-six francs per mile; the gross income on the Belgian Rail Roads, will therefore also in future, like the first year, amount to about thirty-two thousand francs per mile of road annually. That by the increase of population and commerce, also, this income of thirtytwo thousand francs will be increased, is evident; the Rail Roads in Belgium serve therefore as a proof, that long lines of Rail Roads may (some extraordinary circumstance excepted,) be executed with equal success as short ones. 


\section{Rail Roads of Belgium and the United States Compared.}

It would be quite erroneous in calculating the repenue of a system of Rail Roads, Canals, or Turnpike roads, to regard the income on the principal line separately, and so the revenue of each of the branch lines, in order to judge of the value of each of them. By the opening of a branch line the income of the main line mugt become greater; because the passengers and freight from the branch lines will pass over the same and increase the revenue. The accurate way of calculating a whole system of Rail Roads, Canals, or Turnpike roads, must therefore be to compare the total income of the main line as well as of the branch lines, with the total length of all the lines, in order to find the average income per mile; and in deducting therefrom the expenses, the balance will show, when compared with the cost of construction per mile, what interest ensues for the capital invested.

\section{IJudget for the Operations of the Belgian Rail Roads in the Year 1839.}

We have seen that the annual gross income amounts to thirty-two thousand francs per mile, therefore for the one hundred and fifty-nine miles, which are in operation to five million eighty-eight thousand francs. After defraying all the expenses from one hundred francs gross receipts there remain thirt $y$-four francs forty-one centimes, the nett incone will, therefore, be one million seren hundred and fifty thousand seven hundred and eighty francs, instead of which the minister in his Budget anticipates the amount at one million seven hundred thousand, to which he is led by a different calculation. This surplus is exactly five per cent. of the capital expended of thirty-four million francs. These five per cent. suffice for interest and sinking fund, and therefore the Belgian Rail Roads fulfil their object, to maintain themselves without being a charge to the State Treasury.

\section{Increase of Income from the Mail and Turnpikes.}

As an objection against Rail Roads it was further maintained, that their introduction in a country will lessen considerably the receipts of tolls on turnpike roads and of the mail, because there will be less travel on turnpike roads, and letters will be carried by persons who travel on Rail Roads; the same opinion appears to have existed in Belgium. On the 27 th of January 1858, the Minister, Mr. Nothomb, declared in the Senate, that the revenue of the mail in 1837 exceeded that of 1836 by two hundred and sixty-two thousand three hundred and seventy-three francs, and the tolls on turnpike roads by one hundred and ten thousand francs, for the reason that although the tolls on those roads which go in a parallel direction with Rail Rosds are lessened, yet they are increased in a greater proportion on those turnpike roads which lead to the Rail Roads, as they are passed over by all who come to travel on the latter. The revenue from the mail increased in consequence of the greater intercourse occasioned by the introduction of Rail Roads.

\section{Comparison of the Belgian Rail Roads with those in the United States.}

According to Table under No. III, the number of passengers during three and a half $y$ ears, reduced for the length of one mile, amounted on the Belgian Rail Roads to eighty-eight million nine hundred and eighty-one thousand seven hundred and six ty-three, or at an average per year of twenty.five million four hundred and twenty-three thousand three hundred and sixty-one. As the average length of road in operation during the whole time was 53.1 miles, we have four hundred and seventy-eight thousand 
seven hundred and eighty.three through passengers, annually. The Belgian Rail Roads are therefore traveled over on their whole length by nearly five hundred thousand passengers per year. We have now the following comparison:

(a.) Cost of construction.-A mile of Rail Road with a single track, and the necessary buildings and outfit, costs in America twenty-thousand dol. lars; in Belgium forty-one thousand three hundred dollars, or more than twice the amount.

(b.) Tariff--On the American Rail Roads, a passenger pays at an average five cents per mile; on the Belgian Rail Roads, only one cent or five times less; for freight the charge is, in America, at an average seven and a half cents per ton per mile.

(c.) Speed.-On the American Rail Roads, passengers are conveyed with a speed of from twelve to fifteen miles per hour, stoppages included, on the Belgian Roads at the rate of seventeen miles, or stoppages not included; at the rate of from twenty to twenty-five miles.

(a.) Traffic.-There are at an average, thirty.five thousand through passengers, and fifteen thousand tons of goods carried annually over the American Roads; on the Belgian there have been carried per year four hundred and seventy eight thousand seven hundred and eighty-three through passengers, and the transportation of goods only commenced a short time since.

(e.) Gross income. - The same amounts on the American Rail Roads, at an average per mile and per year,

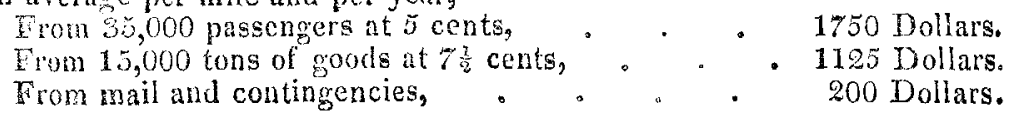

$$
\text { Total, } 3075 \text { Dollars. }
$$

On the Belgian Rail Roads the gross income per mile from four hundred and seventy-eight thousand seven hundred and eighty-three passengers, and the transportation of freight, amounts to thirty-two thousand francs or six thousand and three dollars seventy-five cents per year.

(f.) Expenses per mile of travel - These amount on the American Rail Roads to one dollar, on the Belgian Roads to one dollar five cents, or they are the same in both countries.

(g.) Number of passengers per trip.-In Belgium there were in each train, at an average of three and a half years, one hundred and forty-three throught passengers; on the American roads, a passenger train contains only forty through passengers, at an average.

(h.) Number of trips per year. - In dividing thirty-five thousand by forty we obtain eight hundred and seventy-five, as the average number of passenger trips per year on the American Rail Roads; and in dividing four hundred and seventy-eight thousand seven hundred and eighty-three by one hundred and forty-three we get three thousand three hundred and forty. eight, which represents the average number of passenger trains passing annually over the Belgian roads. As at the same time the speed on the latter is greater than on the American Rail Roads, it was necessary to employ rails of forty.five pounds per yard, while their weight is generally less on the American Rail Roads.

(i.) Expenses per passenger per mile. - These are in Belgium only 0.73 cents, and in America two and a half cents, or three and a half times more. The reason of this is, that the American trains contain three and a half times less passengers, while the expenses per train per mile are equal in both 
countries. It is very nearly the same for a Locomotive to carry forty or one hundred and forty-thre e passengers in a train.

(k.) Annual current expenses. $\rightarrow$ In America the annual current expenses for working a Rail Road, are per mile,

For transportation of 35,000 passengers, at $2 \frac{1}{2}$ cents,

For transportation of 15,000 tons of goods at $6 \frac{1}{2}$ cents,

For transportation of the mail and other expenses,

875 Dollars.

975 Dollars.

100 Dollars.

Total, 1950 Dollars.

Or sixty-three dollars forty-one cents of every one hundred dollars gross income. On the Belgian Rail Roads, of every one hundred dollars gross revenue, the expenses are sixty-five dollars fifty-nine cents, or per year per mile three thousand nine bundred and thirty-seven dollars eighty-six cents.

(l.) Interest on the capital invested.-In America the annual average gross income, per mile of Road, amounts to 3075 dollars, the annual current expenses to one thousand nine hundred and fifty, leaving one thousand one hundred and twenty-five dollars; which compared with the cost of a mile of Road (twenty thousand dollars, give five and a half per cent. interest. On the Rail Roads in Belgium, the annual gross income per mile, is six thousand and three dollars seventy-five cents, the expenses three thousand nine hundred and thirty-seven dollars eighty-six cents, leaving two thousand and sixty-five dollars eighty-nine cents as interest on the cost of forty-one thousand three hundred dollars per mile, or exactly five per cent.

\section{General Remarks.}

The comparison of the results of the Belgian Rail Roads with those of the Rail Roads in the United States of America, speaks evidently in favour of the former. 'The extremely low charges for passage on the Belgian Rail Roads has increased the number of passengers in an unparalleled degree, and produced an intercourse not attained in any other country of the world. While the higher prices in the better classes of cars yield a considerable profit, the price in the last class, or for the great mass of the people, is so low that it about covers the expenses only. The Belgian Rail Roads are, therefore, throughout, a great popular, democratic establishment, which must have met the approbation of the people, and of every intelligent man; the Belgian Rail Roads afford to the government the greatest facility in the transportation of troops, the importance of which was evinced principally during late years; the Belgian Rail Roads yield, in conformity with the grand idea of their establishment, only the interest and sinking fund of their capital, but the State Treasury has, by the increase of intercourse, indirectly, gained in all taxes, in the revenue from tolls on turnpike roads, and from the mail; the most important gain, however, was that kept in view by the great founder of these roads, to bring the nation into a more intimate contact, and to form of it one large family, on which the actual national device: "L'Union fait la force," ("Union gives strength,") becomes realized.

F. A. Cheyalier de Gersther.

** Letters to whom may be addressed to the care of Messrs. Maitland, Kennedy \& Co., New York.

25 Five francs and thirty-three French centimes are equal to one dollar. One English mile is equal to one thousand six hundred and ten metres. One pound sterling is equal to four dollars eighty-six cents.

Cincinnati, 25th June, 1839. 